\title{
PERILAKU PRODUSEN INDUSTRI KECIL DAN RUMAH TANGGA DI KALANGAN MASYARAKAT HOME INDUSTRI SONGKOK DI KECAMATAN GRESIK
}

\author{
Muchammad Nurif
}

\begin{abstract}
Abstrak
Industri songkok tersebar hampir diseluruh wilayah kecamatan Gresik, bahkan sekarang mulai merambah di wilayah-wilayah lain, seperti kecamatan Bunga, Manyar, dan Sedayu. Songkok merupakan salah satu busana tradisional yang sampai saat ini tetap dibutuhkan oleh masyarakat. Awalnya, songkok hanya dipakai oleh masyarakat Gresik sebagai busana tradisional, namun kenyataan bahwa ternyata songkok dipakai sebagai busana tradisional di tempat-tempat lain seperti; madura, betawi dan sebagainya, bahkan dipakai sebagai busana nasional.

Dari hasil survei di lapangan, di daerah home industri songkok di kecamatan Gresik, maka dibutuhkan langkah-langkah untuk memperbaiki kondisi mereka, sebagai berikut: (1) Survei pemasaran, penelitian komoditi, merancang profil industri songkok kecil dan rumah tangga, mendaftar secara sistematis permasalahan yang mereka hadapi; (2) Pembentukan pusat industri kecil dan rumah tangga songkok; (3) Membentuk pusat pelayanan teknis untuk membantu permasalahan teknis industri songkok dalam menciptakan desain serta penyediaan bahan baku; (4) Melakukan pendidikan dan pelatihan bagi para wirausahawan dan pengrajin songkok. Pelatihan yang diberikan meliputi: managemen, pemasaran dan koperasi; (5) Promosi dan pemasaran hasil industri songkok kecil dan rumah tangga.

Industri songkok kecil dan rumah tangga, banyak yang gulung tikar disebabkan oleh karena kalah bersaing dengan industri songkok besar. Industri songkok besar ini mampu menghasilkan produk-produk songkok yang bermutu, sehingga praktis mereka yang menguasai pasaran songkok. Dengan kata lain, adanya praktek monopoli yang menjadi penghambat perkembangan industri songkok kecil dan rumah tangga.
\end{abstract}

Kata kunci: Industri Kecil dan Rumah Tangga, Home Industri Songkok, Koperasi

Dalam menghadapi era globalisasi saat ini, peningkatan kesejahteraan pekerja masih menjadi isu penting di Indonesia sejak decade 1980an. Sorotan masyarakat internasional terhadap masalah pekerja yakni Hak Asasi Manusia dan tingkat upah yang rendah. Agenda globalisasi dan pasar bebas merupakan tantangan yang harus 
dihadapi, apalagi Indonesia bertekat mensejajarkan diri dengan bangsa-bangsa lain di dunia. Pada hal dari segi ekonomi mereka sudah jauh meninggalkan Indonesia, di tambah lagi krisis yang semakin menekan ini. Dengan alasan ini diperlukan suatu tindakan konkret mulai sekarang.

Tantangan yang sudah jelas dan konkret di depan mata adalah liberalisasi perdagangan. Di wilayah Asia Pasifik, jadwal yang sudah ditetapkan pada tahun 2020, sebagaimana disepakati dalam pertemuan APEC. Sementara untuk wilayah Asean melaui AFTA (Asean Free Trade Area), ditetapkan pada tahun 2003. Ada banyak pendapat terlontar berkaitan dengan munculnya gagasan pasa bebas. Satu pihak, mengkhawatirkan timbulnya ketergantungan-ketergantungan negara-negara berkembang terhadap negara-negara maju. Alasannya, ketika gagasan liberalisasi dicanangkan, sumber daya manusia di negara berkembang belum disiapkan. Begitu pun dengan pranata-pranata social, politik, ekonomi belum kukuh. Dengan begitu, ketergantungan terhadap negara maju bukan hanya di bidang ekonomi, tetapi juga budaya.

Diskusi yang serius mengenai industri kecil dan rumah tangga di Indonesia barulah terjadi pada tahun 1970-an. Sebelumnya, industri kecil dan rumah tangga hanya disebut-sebut secara tidak langsung. Mohammad Hatta (almarhum), mantan Wakil Presiden Republik Indonesia dan seorang ekonom, misalnya hanya menggunakan istilah industri rakyat untuk apa yang sekarang ini disebut industri kecil ( Rahardjo, 1974a). Kendati demikian, hal ini bukan berarti bahwa industri kecil dan rumah tangga tidak berkembang di Indonesia.

Menurut Direktorat Industri Skala Kecil dan Departemen Industri, unitunit perusahaan industri skala kecil tersebut sangat bervariasi. Dalam perusahaan yang menghasilkan barang logam, dari bahan perlengkapan dapur sampai pengecoran suku cadang bagi peralatan industri, beberapa jenis sulaman, batik; beberapa jenis anyaman (produk-produk jerami seperti keranjang dan kesetan); kayu dan kulit; konveksi dan songkok; serta pengolahan makanan dan minuman. Semua perusahaan tersebut di kelompokkan sebagai industri kecil. 


\section{Home Industri “ SONGKOK” di Kabupaten Gresik}

Industri songkok tersebar hampir diseluruh wilayah kecamatan Gresik, bahkan sekarang mulai merambah di wilayah-wilayah lain, seperti kecamatan Bunga, Manyar, dan Sedayu. Industri songkok ada sejak sebelum jaman kemerdekaan RI. Terbukti para pejuang-pejuang kemerdekaan banyak yang menggunakan songkok sebagai busana resmi kenegaraan termasuk Presiden RI pertama, Bung Karno. Awalnya industri songkok ini hanya dihasilkan dalam skala kecil untuk memenuhi permintaan masyarakat sekitar gresik, namun sekarang industri ini berkembang, baik dalam skala kecil maupun dalam skala industri rumah tangga bahkan sampai industri skala besar dengan modal yang cukup besar pula sampai skala ekspor. Songkok merupakan salah satu busana tradisional yang sampai saat ini tetap dibutuhkan oleh masyarakat. Awalnya, songkok hanya dipakai oleh masyarakat Gresik sebagai busana tradisional, namun kenyataan bahwa ternyata songkok dipakai sebagai busana tradisional di tempat-tempat lain seperti; madura, betawi dan sebagainya, bahkan dipakai sebagai busana nasional.

Namun akhir-akhir ini, produksi songkok hanya di dominasi oleh kalangan tertentu yang memiliki modal besar. Upaya untuk membantu para pengrajin kecil sudah banyak dilakukan, tapi belum membuahkan hasil yang maksimal, sehingga dibutuhkan kesadaran masyarakat home industri songkok tentang arti pentingnya sebuah organisasi yang berfungsi mewadai kepentingan mereka. Langka ini bisa bertujuan untuk memberikan bantuan kepada kelompok-kelompok yang secara ekonomi lemah di kalangan para pengusaha songkok untuk skala kecil.

Disamping itu juga perlu dikembangkan kerja sama antara pengusaha kecil dan menengah maupun besar dengan, sistem bapak angkat . Dalam pola ini, pengusaha besar "mengangkat" beberapa pengusaha kecil, memberikan bantuan seperti penyediaan bahan baku, desain, pelatihan ( managemen dan pemasaran ) serta bila perlu membeli produk-produk (output) mereka yang menjadi anak angkat. Dengan demikian dapat diharapkanbahwa kehadiran industri kecil dan rumah tangga 
akan diakui sebagai bagian dan industri nasional dan sistem ekonomi. Untuk melengkapi sistem bapak angkat ini juga telah dikembangkan pula sistem subkontrak.

\section{Fungsi Produksi}

Dalam teori ekonomi seorang produsen atau pengusaha harus dapat memutuskan dua macam keputusan :

a. Berapa output yang harus diproduksi;

b. Berapa dan dalam kombinasi bagaimana faktor-faktor produksi (input) dipergunakan. Semuanya diputuskan dengan menganggap bahwa produsen atau pengusaha selalu berusaha untuk mencapai keuntungan maksimal. Asumsi dasar lainnya adalah bahwa produsen atau pengusaha beroperasi dalam pasar persaingan sempurna. Pasar persaingan sempurna adalah pasar dimana (a) harga output dan input ditentukan oleh pasar; (b) produsen tidak punya kekuasaan untuk mempengaruhi pasar; (c) jumlah produsen banyak dan volume produksi setiap produsen hanya merupakan bagian yang kecil dari volume transaksi total di dalam pasar; (d) produk yang dihasilkan oleh para produsen adalah "homogen" sehingga produksi satu produsen merupakan substitusi yang sempurna bagi hasil produsen lain; (e) setiap produsen bisa mendapatkan informasi pasar (harga yang berlaku) dengan cepat dan tepat. (Boediono, 1998) Perhatikan bahwa semuanya yang disebut diatas adalah penyederhanaan dari perilaku seorang pengusaha dalam kenyataan, dimana ia harus memutuskan berbagai macam hal lain (misalnya: hutang - piutang, operasional produksi, pemasaran, masalah perburuhan, penyediaan bahan baku dan hal - hal administrasi lainnya).

\section{Proses Produksi}

Yang dimaksud dengan fungsi produksi adalah hubungan teknis yang menghubungkan antara faktor produksi atau disebut pula masukan atau input dengan 
hasil produksinya atau produk (output). Fungsi produksi menggambarkanteknologi yang dipakai. Dalkam keadaan teknologi tertentu hubungan antara input dan outputnya tercermin dalam rumusan fungsi produksinya. Suatu fungsi produksi, menggambarkan semua metode produksi yang efisien secara teknis dalam arti menggunakan kuantitas bahan baku yang minimal, tenaga kerja minimal, dan barangbarang modal lain yang minimal.

Pada dasarnya yang dimaksud dengan metode produksi adalah suatu kombinasi dari faktor-faktor produksi yang dibutuhkan untuk memproduksikan satusatuan produk. Biasanya untuk menghasilkan satu-sastuan produk dapat digunakan lebih dari satu metode atau proses atau aktivitas produksi. Misalnya satu-satuan bahan songkok $\mathrm{X}$ dapat diproduksikan oleh tiga macam proses :

\section{Proses P-1 Proses P-2 Proses P-3}

$\begin{array}{llll}\text { Tenaga Kerja } & 3 & 4 & 2 \\ \text { Modal } & 5 & 4 & 6\end{array}$

Faktor produksi memang banyak, tetapi dari yang banyak itu dapat disederhanakan menjadi dua dimana perilakunya berbeda dan dapat segera dikontraskan. Dalam jangka pendek faktor produksi tenaga kerja dianggap sebagai faktor produksi variabel yang penggunaannya berubah-ubah sesuai dengan perubahan volume produksi. Sedangkan faktor produksi modal dianggap sebagai faktor produksi yang tetap dalam arti bahwa jumlahnya tidak berubah dan tidak terpengaruh oleh perubahan volume produksi.

Dalam teori ekonomi diambil satu asumsi dasar mengenai sifat dari gungsi produksi, yaitu fungsi produksi dari semua produksi dimana semua produsen dianggap tunduk pada suatu hukum yang disebut : Law of Diminishing Return. Hukum ini meyatakan bahwa bila satu macam input ditambahkan penggunaannya sedang input-input yang lain tetap maka tambahan output yang dihasilkan dari setiap tambahan satu unit input yang ditambahkan tadi mula-mula menaik, tetapi kemudian seterusnya menurun bila input tersebut terus ditambahkan. 


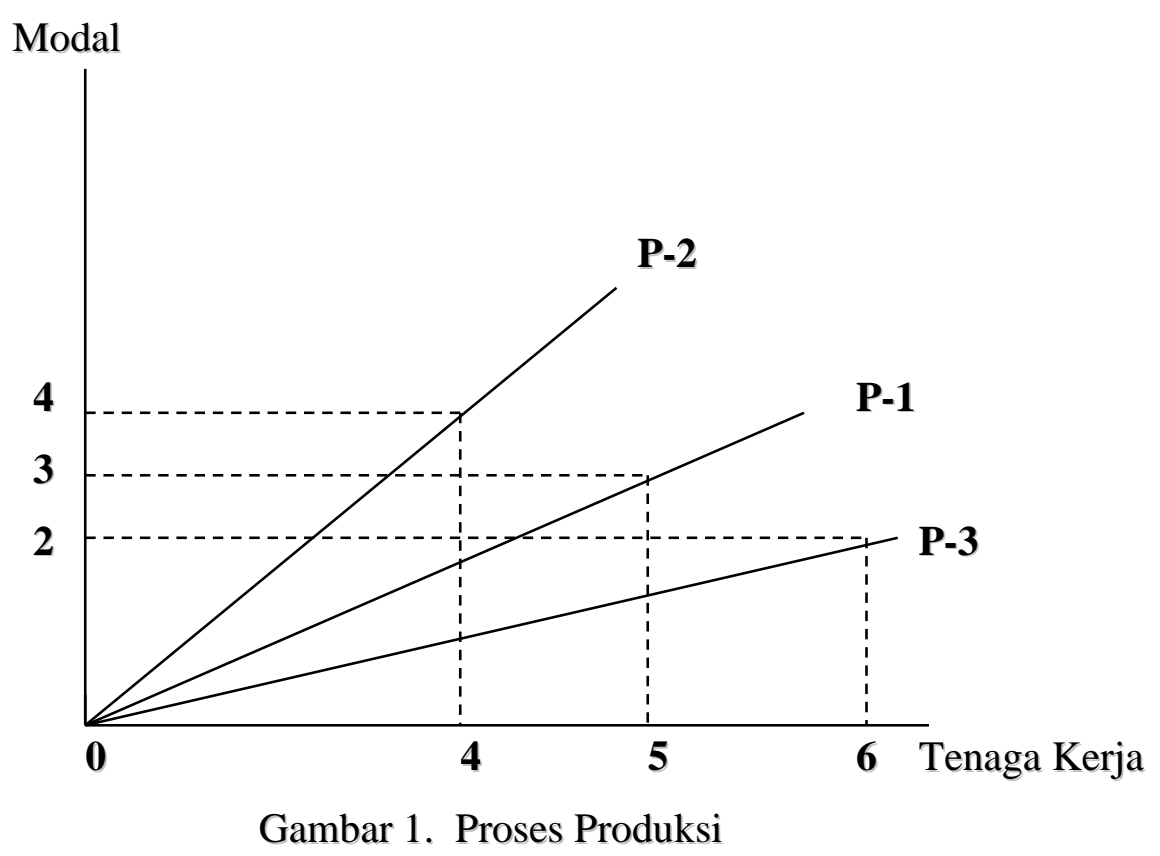

Dari ketiga proses ini harus dipilih yang secara teknis efisien. Proses yang terpilih mencerminkan kombinasi faktor tenaga kerja dan modal yang dapat menghasilkan satu satuan produk secara teknis efisien. Hubungan antara tenaga kerja dan modal pada satu pihak dengan volume produksi pada pihak lain merupakan fungsi produksi. Satu proses dalam gambar diatas mencerminkan fungsi produksi yang bersifat sebanding (fixed proportion), artinya produsen dapat menghasilkan 10 kali lipat satuan produksi asal kuantitas tenaga kerja dan modal juga dikalikan dengan kelipatan yang sama, sehingga perbandingan antara kuantitas tenaga kerja dan modal juga tetap.

Sebenarnya gambar tersebut secara keseluruhan sudah menggambarkan hal ini dalam pengertian bahwa satu satuan produksi dapat dihasilkan oleh tiga macam proses produksi yang mempergunakan tenaga kerja dan modal dalam perbandingan yang berbeda-beda. Akan tetapi gambar tersebut belum mencukupiu. Pertama jumlah metode terbatas pada tiga. Meskipun jumlah ini dapat ditambahkan sekehendak kita tetapi tetap belum mencukupi. Sebab 
sekali kita memilih satu macam proses akan berlaku pola kombinasi faktor produksi yang sebanding. Untuk menggambarkan pola kombinasi faktor produksi yang tidak sebanding (variable proportions) biasanya digunakan isoquant (iso quantities) yaitu kurva yang menggambarkan berbagai kombinasi faktor produksi (tenaga kerja dan modal) yang menghasilkan volume produksi yang sama, misalnya 1000 satuan produk (iso = sama).

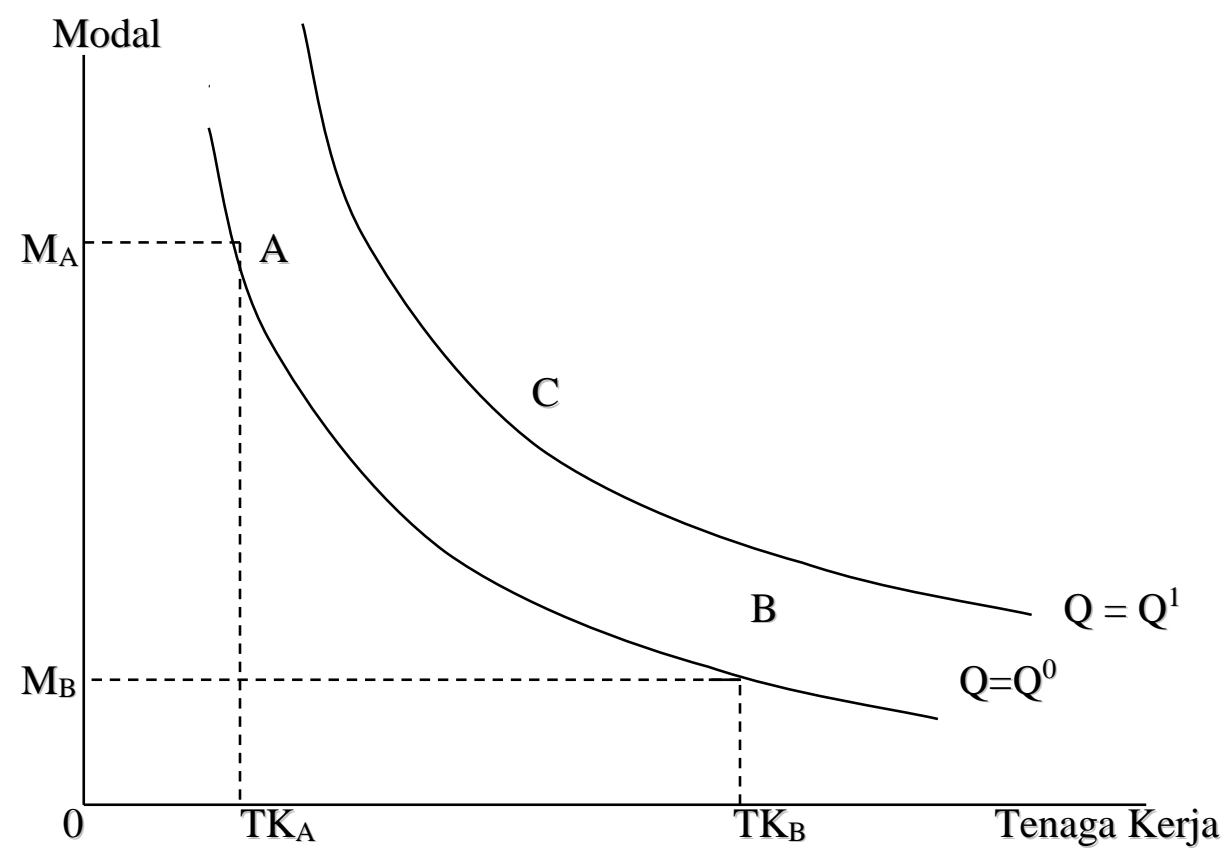

Gambar 2. Isokuan

Isoqunt mempunyai sifat-sifat yang serupa dengan indifference curve konsumen. Cembung kearah origin, menurun dari kiri kanan bawah, output makin tinggi bagi kurva yang terletak lebih kanan atas. Kegunaan dari isoquant adalah untuk menentukan Least Cost Combination, yaitu kombinasi penggunaan input-input untuk menghasilkan suatu tingkat output tertentu dengan ongkos total yang minimum (Sudarsono, 1995)

\section{Aspek-aspek Keuangan Home Industri “ SONGKOK” Di Kabupaten Gresik:}




\section{Kebutuhan Dana}

Kebutuhan dana dapat dibagi dalam kebutuhan jangka panjang dan jangka pendek. Kebutuhan dana jangka panjang tampak pada awal mendirikan usaha, dan ketika usaha berkembang. Kebutuhan-kebutuhan tersebut terdiri dari pembelian peralatan, transportasi, biaya relokasi atau ekspansi dan biaya promosi. Kebutuhan-kebuituhan jangka pendek atau variable berubah menurut syarat-syarat waktu; hal ini terdiri dari pembayaran upah, biaya produksi lainnya, dan kredit berdasarkan peningkatan permintaan. Mereka menyatakan bahwa asset tetapnya cukup, tetapi modal kerja mereka terlalu kecil. Karena itu tidak salah kalau kesulitan-kesulitan muncul ketika perusahaan memperoleh pesanan tanpa pembayaran di muka atau mengajukan permohonan pesanan barang-barang secara kredit.

Bagi sebagian besar industri kecil dan rumah tangga di Indonesia, termasuk pada survai kami di daerah kecamata Gresik. Permasalahannya adalah penentuan sumber-sumber modal perusahaan secara cermat. Hal ini di sebabkan kurang tersedianyalaporan-laporan keuangan. Dengan demikian, pada survai kami ini hampir 30\% tidak ada laporannya sama sekali, sedangkan sisanya $70 \%$ pembukuannya belum sempurna.

Sesuai dengan prosedur usaha informal yang dilakukan oleh industri kecil dan rumah tangga, lembaga-lembaga keuangan formal tidak banyak di manfaatkan. Ketika diajukan pertanyaan mengenai sumber dana asset modal yang ada, 37\% menyebut berasal dari warisan, sedangkan $63 \%$ berasal dari tabungan pribadi. Kalau industri kecil dan rumah tangga " Songkok “ ini tidak memperoleh pinjaman jangka panjang, koperasi lebih sering dimanfaatkan dari pada bank komersial. Bagi mereka koperasi merupakan sumber pinjaman jangka panjang yang persentasenyamencapai du a kali lipat dari pada bank komersial (40\%dibandingkan dengan 18,8\%). Dalam hal ini, suku bunga yang dikenakan koperasi jauh lebih tinggi dari pada bank komersial, yakni sekitar 
2-3\% per bulan. Produk pinjaman jangka panjang yang besar berasal dari “ lain-lain" dalam factor informal seperti individu dan para pemberi pinjaman

\section{Permasalahan Fundamental Industri Kecil dan Rumah tangga}

Kenyataan telah menunjukkan bahwa negara-negara penganut paham liberalisme jauh lebih maju dibanding lainnya. Indikatornya, bisa dilihat pada perdagangan dunia yang terus meningkat dengan diberlakukannya sistem perdagangan bebas. Dengan meningkatnya volume perdagangan, berarti terjadi peningkatan produksi. Ini tentu saja mengimbas pada peningkatan lapangan kerja, yang seterusnya meningkatkan pendapatan dan kesejahteraan. Oleh karena itu, yang timbul justru persoalan, bagaimana memperoleh keuntungan yang sebesarbesarnya dengan mengurangi kemungkinan kerugian, terutama bagi usaha kecil dan rumah tangga. Pilihannya hanya satu, meningkatkan daya saing. Sumbernya melalui efisiensi dan produktivitas (peningkatan nilai tambah) dengan memanfaatkan pasar dalam negeri dan secepatnya ketergantungan pada pasar domestik mesti ditinggalkan dan beralih ke pasar internasional.

Selain permasalahan fundamental yang perlu diselesaikan, berkaitan dengan kondisi yang sudah berlangsung di negeri ini. Kelompok industri kecil dan rumah tangga, yang jumlahnya mayoritas mendapat kesulitan dalam hal SDM dan akses pasar. Ini merupakan warisan dari pemerintah lama yang memberikan kesempatan luar biasa kepada pengusaha besar. Misalnya, untuk akses pasar mereka diberikan proteksi yang berlebihan. Dengan alasan ini, pilihan yang harus ditempuh adalah pemihakan yang tegas terhadap pengusaha kecil. Ini diwujudkan dalam langka-langkah strategis dalam rangka memperbaiki kondisi keterbelakangan dan memperkuat daya saing ekonomi rakyat (industri kecil dan rumah tangga). Prinsip yang perlu menjadi pegangan, ditengah ketatnya persaingan, ekonomi rakyat mesti memiliki kreasi, inovasi, produktivitas tinggi, dan kemampuan membaca peluang yang lebih baik. Catatan ini harus dipegang teguh, seandainya ini keluar sebagai pemenang dalam persaingan tersebut. 
Catatan ini merupakan ciri dari ekonomi rakyat yang berbasiskan keunggulan kompetitif. Dalam penentuan keunggulannya, keunggulan kompetitif lebih bertumpu pada sumber daya manusia berketrampilan tinggi dan penguasaan teknologi yang memadai walaupun bukan teknologi tinggi. Prinsip ini sangat berbeda dengan keunggulan kandungan yang melimpah, yaitu sumber daya alam dan buruh murah yang tidak berketrampilan. Jika industri kecil dan rumah tangga sudah mencapai sebagaimana diatas, maka sangat mungkin bersaing dalam pasar bebas nanti.

Secara politis, format ekonomi baru tidak lain dimaksudkan untuk menciptakan suatu tatanan perekonomian yang berbasis prinsip pasar yang diiringi dengan deregulasi yang memihak pada kepentingan rakyat banyak. Meskipun format itu memihak pada kepentingan rakyat, bukan berarti dunia usaha berskala besar akan dihancurkan apalagi dilarang. Sebab yang diperjuangkan tidak lain adalah aturan yang tegas dan jelas, transparansi serta pemisahan kekuasaan politik dengan kegiatan ekonomi yang menjadi prinsip fair yang melandasi kehidupan ekonomi masa datang. Paradigma ekonomi yang baru ini, diharapkan dapat mendorong tumbuhnya partisipasi masyarakat secara luas dalam bentuk tumbuh dan berkembangnya industri kecil dan rumah tangga serta koperasi yang selama ini masih tertinggal. Khusus mengenai usaha-usaha menengah posisinya sangat penting untuk mengisi holo middle. Selama ini masalah itu menjadi persoalan besar dalam ciri yang bersifat dualistik dari struktur ekonomi nasional yang kurang menguntungkan.

Pertama, struktur ekonomi nasional dicirikan oleh kesenjangan yang lebar antara pengusaha besar dan kecil. Kedua, tidak adanya keterkaitan yang berarti antara usaha besar dan usaha kecil. Disinilah letak pentingnya keberadaan usaha berskala menengah dalam memperkokoh struktur ekonomi nasional. Pengembangan kemandirian ekonomi dilakukan melalui langkah memperkuat ekonomi domestik yang utamanya didukung oleh sektor industri kecil dan rumah tangga serta sektor pertanian. Perhatian yang besar terhadap pembangunan sektor 
pertanian perlu diberikan dalam rangka kepentingan ekonomi rakyat. Alasannya, di sektor ini masih banyak potensi yang dapat dikembangkan untuk kepentingan masyarakat khususnya pedesaan. Peningkatan pendapatan masyarakat pedesaan pada gilirannya akan meningkatkan permintaan terhadap barang-barang industri yang pada akhirnya akan menumbuhkan aktivitas ekonomi secara keseluruhan.

Perusahaan-perusahaan skala kecil dan rumah tangga ini hampir terdapat dimanapun, di daerah maju, berkembang dan terbelakang, maupun daerah perkotaan dan pedesaan. Polanya di daerah perkotaan berbeda dengan daerah pedesaan. Sektor-sektor paling mencolok di daerah perkotaan adalah sektor perdagangan dan sector jasa, sedangkan yang paling mencolok di daerah pedesaan adalah sector pertanian dan sebagian kecil sector perdagangan. Karena itu ada semacam keharusan untuk mengembangkan unit-unit perusahaan skala kecil, sebab dengan mengembangkannya juga berguna untuk program distribusi pendapatan.

Industri kecil dan rumah tangga telah berbukti menunjukkan keunggulan dan menjadi katup pengaman dalam keadaan krisis ekonomi dan moneter yang melanda negara kita. Oleh karena itu, perhatian yang lebih serius oleh pemerintah terhadap industri kecil dan rumah tangga semakin nyata terlihat. Pemerintah secara terbuka menjalankan kebijakan yang berpijak diatas dua kaki, yakni mengembangkan industri besar dan menengah maupun industri kecil dan rumah tangga secara serentak.

Tumbuhnya perhatian terhadap industri kecil dan rumah tangga ini tampaknya merupakan tanggapan pemerintah atas kritik pada strategi terdahulu yang dianggap terlalu menekankan pembangunan ekonomi dan industrialisasi dengan mengorbankan pemerataan distribusi pendapatan. Karena itu, pembangunan sektor industri kecil dan rumah tangga dianggap merupakan cara untuk memeratakan pendapatan. 
Dari hasil survai kami di lapangan, di daerah home industri songkok di kecamatan Gresik, maka dibutuhkan langkah-langkah untuk memperbaiki kondisi mereka, sebagai berikut :

1. survai pemasaran, penelitian komoditi, merancang profil industri songkok kecil dan rumah tangga, mendaftar secara sistematis permasalahan yang mereka hadapi;

2. pembentukan pusat industri kecil dan rumah tangga songkok;

3. membentuk pusat pelayanan teknis untuk membantu permasalahan teknis industri songkok dalam menciptakan desain serta penyediaan bahan baku;

4. melakukan pendidikan dan pelatihan bagi para wirausahawan dan pengrajin songkok. Pelatihan yang diberikan meliputi: managemen, pemasaran dan koperasi;

5. promosi dan pemasaran hasil industri songkok kecil dan rumah tangga

Untuk mengembangkan industri songkok kecil dan rumah tangga ini, pemerintah daerah berupaya, diantaranya telah menciptakan berbagai fasilitas mulai dari perkreditan sampai dengan upaya memecahkan masalah pemasaran dan perolehan bahan baku melalui program Bapak Angkat. Sehingga diperlukan langkahlangkah konkrit untuk menjawab permasalahan diatas, sebagai berikut :

\section{Ketidakmampuan para pengusaha industri songkok kecil dan rumah tangga bersaing dengan industri songkok besar}

Industri songkok kecil dan rumah tangga, banyak yang gulung tikar disebabkan oleh karena kalah bersaing dengan industri songkok besar. Industri songkok besar ini mampu menghasilkan produk-produk songkok yang bermutu, sehingga praktis mereka yang menguasai pasaran songkok. Dengan kata lain, adanya praktek monopoli yang menjadi penghambat perkembangan industri songkok kecil dan rumah tangga. Di samping industri songkok kecil dan rumah tangga ini harus menghadapi dominasi industri songkok besar dalam hal pemasaran produk mereka, pengusaha industri songkok kecil dan rumah tangga harus menghadapi monopoli 
dalam hal perolehan bahan baku. Sejak masa pemerintahan colonial sampai saat ini pemasaran bahan baku songkok pada umumnya dikuasai oleh sekelompok pengusaha tertentu saja. Akibatnya harga bahan baku songkok menjadi sangat fluktuatif tergantung dari kehendak si pengusaha bahan baku itu, terutama pada bahan baku "bludru” atau kain sutra untuk lapisan songkok bagian luar. Bagi para pengusaha industri songkok kecil dan rumah tangga keadaan seperti ini sering menimbulkan kesulitan yang kemudian berakhir dengan kebangkrutan usaha mereka.

\section{Rendahnya daya beli masyarakat pada produk songkok.}

Pada umumnya konsumen akan membeli songkok pada saat-saat tertentu saja, misalnya pada saat menjelang Hari Raya Idul Fitri atau mau melaksanakan pernikahan (Manten). Situasi seperti ini yang umumnya dihadapi oleh pengusaha industri songkok kecil dan rumah tangga. Untuk membantu mengatasi masalah ini, pemerintah daerah menciptakan kebijanakn hubungan Bapak Angkat antara industri songkok besar dengan industri songkok kecil dan rumah tangga. Segi positif dari kebijakan ini adalah bahwa industri songkok kecil dan rumah tangga dapat memperoleh bantuan pemasaran produk mereka dari industri songkok besar serta kemudahan lain seperti kemudahan memperoleh bahan baku. Namun kebijakan huungan Bapak Angkat ini juga memiliki segi negative terhadap perkembangan industri songkok kecil dan rumah tangga. Sistem Bapak Angkat sering berkembang menjadi wahana bagi si Bapak Angkat untuk mengeksploitasi dan mengalihkan sebagian resiko perusahaannya kepada anak angkatnya. Di samping itu system Bapak Angkat ini menjadikan anak angkat hanya berkedudukan sebagai "buruh" dari Bapak Angkat, karena hidup matinya anak angkat tergantung dari kebaikan hati Bapak Angkat dalam memberi kontrak kerja kepada si anakn angkat dan "upah" yang diterimanya.

Tidak adanya suatu organisasi yang mampu memperjuangkan dan melindungi aspirasi serta kepentingan industri songkok kecil dan rumah tangga 
Pembinaan terhadap industri kecil dan rumah tangga termasuk industri songkok hanya dilakukan oleh pemerintah. Dan karena dilakukan oleh pemerintah, maka pembinaan tersebut bersifat birokratif dan sering tidak mengenai sasaran. Pemerintah dalam usaha menciptakan organisasi bagi industri kecil dan rumah tangga ini telah membentuk koperasi dan menganjurkan para pengusaha untuk menjadi anggota koperasi. Tetapi usaha pemerintah itu belum mampu mencapai tujuannya dikarenakan oleh kurangnya antusiasme dikalangan maskarakat home industri songkok ini untuk menjadi anggota koperasi yang menurut mereka tridak mempu melindungi usaha mereka menghadapi persaingan dari industri songkok besar. Kurangnya antusiasme tersebut karena mereka merasa kecewa terhadap koperasi yang dianggap gagal memperbaiki nasib para anggotanya. Bahkan adanya kesan pengurus koperasi menguasai dan menggunakan koperasi untuk kepentingan dan pengembangan usaha mereka sendiri tanpa mengindahkan kepentingan-kepentingan para anggota. Hal ini dapat terjadi karena para pengurus koperasi notabene terdiri dari para pengusaha industri songkok besar saja. Sehingga kesempatan untuk memperoleh "tender" atau pesanan-pesanan dalam jumlah besar hanya dimanfaatkan dan dikuasai sendiri oleh para pengusaha industri songkok besar.

Dari uraian singkat tentang masalah-masalah yang dihadapi oleh industri songkok kecil dan rumah tangga terlihat bagaimana kompleksnya masalah tersebut. Permasalahan-permasalahan itu saling berkaitan satu dengan lainnya, sehingga pemecahannyapun tidak dapat dilakukan secara sektoral, seperti menyediakan kredit atau mendirikan koperasi. Kredit dan koperasi tidak akan banyak bermanfaat bagi perkembangan industri songkok kecil dan rumah tangga selama mereka dibiarkan tanpa perlindungan pemerintah bersaing dengan industri songkok besar dalam pemasaran maupun perolehan bahan baku. Demikian juga dengan sistem Bapak Angkat tidak akan mampu meningkatkan perkembangan industri kecil ini tanpa adanya suatu undang-undang yang melindungi hak anak angkat dalam memperoleh pembagian keuntungan yang wajar dari adanya kerja sama produksi ini. 


\section{Kesimpulan}

Kurang tersedianya modal merupakan masalah penting, Namun, modal juga merupakan masalah bagi pengusaha industri songkok kecil dan rumah tangga dalam pengertian yang lain, yakni para pengusaha masih tetap tidak dapat secara efisien menggunakan modal untuk menghasilkan laba. Modal tetap yang dimiliki oleh pengusaha-pengusaha sebagian besar mencukupi, tetapi modal kerjanya kecil, sehingga menemui kesulitan jika terdapat pesanan tanpa uang muka, atau pembelian dengan kredit.

Kebutuhan dana jangka pendek maupun jangka panjang jarang dibiayai oleh sumber yang laik. Di samping itu, sangat sedikit dari mereka yang melakukan laporan tertulis. Karena itu yang sering terjadi adalah bahwa modal digunakan secara tidak efisien, karena pendanaan yang seharusnya digunakan untuk investasi justru digunakan untuk modal kerja; hal ini membuat pembiayaan modal untuk pengeluaran jangka pendek tidak lagi diperlukan.

Dalam memenuhi kebutuhan dana, khususnya dari sumber-sumber resmi, para pengusaha dihadapkan dengan beberapa masalah. Masalah-masalah tersebut termasuksuku bunga yang tinggi dan birokrasi yang berlebihan, sehingga para pengusaha tidak dapat menggunakan peluang ini. Dengan demikian, para pengusaha memanfaatkan sumber-sumber tidak resmi, seperti para pemasok, pemebri pinjaman, dan perorangan, sekalipun suku bunganya tinggi, tetapi prosedur untuk memperoleh kredit itu mudah.

Para pengusaha dari industri songkok kecil dan rumah tangga masih tetap tidak menerapkan metode manajemen apapun, khususnya manajemen keuangan, dengan menempatkan keuangan secara tertib. Sebagian terbesar dari mereka, misalnya, masih tetap membaurkan uang pribadi dengan uang usaha, sehingga sulit untuk mengetahui berapa besar modal yang dimiliki perusahaan.

Kesulitan/hambatannya antara lain: sumber-sumber resmi: prosedurnya sangat panjang dan sangat birokratis serta banyak waktu dibutuhkan sebelum dana didapat. 
Periode pembayaran kembali terlalu singkat/pendek; koperasi-koperasi: jumlah yang dapat dipinjamkan terbatas, manajemen beberapa koperasi kadang-kadang tidak efisien. Suku bunga kadang-kadang agak tinggi; dan sumber perorangan lainnya: suku bunga sangat tinggi. Dana yang tersedia juga sangat terbatas.

Keuntungan-keuntungannya sebagai berikut: sumber-sumber resmi: suku bunga rendah, pinjaman mungkin besar, walaupun tentu saja terhadap pagu. Secara keuangan lebih aman dan manajemen lebih terlatih; koperasi-koperasi: prosedur

pinjaman mudah, jaminan sering tidak dibutuhkan; sumber-sumber lain : Kebutuhan dana/modal dapat dipenuhi didalam periode waktu yang relative pendek, prosedurnya tidak rumit, lebih hanya berdasarkan pada kepercayaan, dapat dihubungan dimana saja kalau dibutuhkan..

Pola Penggunaan Laba dalam rangka menanamkan modal lebih lanjut jarang dilakukan oleh para pengusaha. Beberapa dari mereka menabung dalam bentuk tanah, rumah, perhiasan, dan sebagainya. Hal ini erat hubungannya dengan persepsi masyarakat mengenai keberhasilan seorang pengusaha, yang harus mampu terlihat secara fisik sebagai kaya, dqan ini mempunyai pengaruh yang besar pada gaya hidup pengusaha bersangkutan. Sebagian terbesar mereka membiayai investasinya dengan kredit, tetapi tidak melalui saham.

\section{Daftar Pustaka}

Boediono, 1998, Ekonomi Mikro, Seri Sinopsis, BPFE, Yogyakarta.

Djojohadikusumo Soemitro, 1998, Dasar Teori Ekonomi Pertumbuhan dan Ekonomi Pembangunan, PT. Pustaka LP3ES Indonesia, Jakarta.

Sudarsono, 1995, Pengantar Ekonomi Mikro, PT. Pustaka LP3ES Indonesia, Jakarta. 